\title{
THE BANCRUPTCY IN THE CZECH REPUBLIC - INFLUENCE OF MACROECONOMIC VARIABLES
}

\author{
Tomáš Moravec $^{1}$ \\ ${ }^{1}$ Vysoká škola ekonomická v Praze, Fakulta mezinárodních vztahů, náměstí W. Churchilla 4, 13067 Praha \\ Email:moravec.thomas@seznam.cz.
}

\begin{abstract}
This article deals with the bankruptcy of entrepreneurial subjects and how bankruptcy rate is affected by macroeconomic variables. The article is based on the time series for the period from 1993 to 2012. The article analyses the influence of GDP, indebtedness of companies, inflation and interest rates on the number of declared bankruptcies. There might be supposed positive or negative correlation between GDP, indebtedness of companies, inflation and interest rates and the number of declared bankruptcies. Also there is tested lag in correlation between number of declared bankruptcies and GDP, indebtedness of companies, inflation and interest rates. My findings in this article confirm strong correlation between GDP, indebtedness of companies, inflation and interest rates and the number of declared bankruptcies.
\end{abstract}

Keywords: bankruptcy, GDP, inflation, interest rates.

JEL classification: G33, K35

Doručeno redakci: 13.10.2010; Recenzováno: 15.3.2013; 17.1.2013; Schváleno k publikování: 19.6.2013

\section{Introduction}

The life of the economic subjects begins and terminates. There is needed to create the procedure regulating the exit of companies from the economy. This involuntary procedure is regulated by insolvency law in the Czech Republic. If the debtor is unable to pay its liabilities or its liabilities are over assets, debtor has the obligation to file insolvency petition. The one of the aim of insolvency law is to decrease losses of the creditors. Moreover, the insolvency law also helps to remove the economic subjects in red numbers from the economy. For creditors and the market, there is important to quickly solve bankruptcy and distribution of assets among the beneficiaries. This quick solution decreases common losses and then economic subjects could be replaced faster. Further, the flexible and transparent processes are essential for well functioning of the economy, because an imperfect and inflexible insolvency law may cause collapse of the economy and bankruptcy of debtor's creditors.

This article deals with the influence of macroeconomic variables on the number of declared bankruptcies in the Czech Republic. Firstly, I introduce different economic models analysing the prediction of bankruptcy. Secondly, I focus on the definition of bankruptcy according to the Czech insolvency law. Thirdly, I analyse Czech macroeconomic data targeting on the relation between bankruptcy and GDP, interest rates, inflation and indebtedness.

This article brings the evidence that there is dependence between the number of declared bankruptcies and GDP, interest rates, inflation, indebtedness. 


\section{The Bankruptcy Prediction}

Several authors deal with the bankruptcy prediction. Studies use different determinants predicting the subsequent rate of bankruptcies. Mostly, the studies are focused on macroeconomic or microeconomic ${ }^{1}$ determinants.

Bernhardsen (2001 p. 4) has introduced the idea that authors should focus on macroeconomic determinants instead of microeconomic determinants. There is Wadhwani's study analyzing the influence of real wages, the cost of inputs, the real interest rate, nominal interest rate and aggregate demand. Wadhwani (1986) has stated that the above mentioned determinants have significant influence (Liu, 2004 p. 1). Davis has used the ratio of debt to GDP in his analysis. Cuthbertson and Hudson have showed in their model that the main variables determining bankruptcy prediction are interest rates, profit and variable income flows (Vlieghe, $2001 \mathrm{p}$. 13). Further, Lennox has showed that the industrial sector, company size and business cycle have a significant effect on business failure and subsequent bankruptcy (Charitu, Neophytou, and Charalambous, 2004 p. 469). Wang (2010 p. 7) tested systematic distress and credit contagion. Koopman Kraussl, Lucas, Monteiro (2009 p. 42) studied the relation between macroeconomic fundamentals. Vlieghe (2001) has tested various hypotheses on empirical data from the United Kingdom. His work has concluded that the significant variables determining bankruptcy rate are nominal interest rates and property prices in short run. In the long run there is important real interest rate. Liu (2004) has examined how macroeconomic variables affected the rate of bankrupted companies in the United Kingdom. He examined data from 1966 to 2003 . He concluded that both short and long term effects of inflationary shocks indicate a high inflation rate. The high inflation rate increases production cost and debt management costs. Due to increasing costs, corporate capital is reduced and the number of bankruptcies increases. Liu (2004) has also showed a correlation between the provided amount of loans and the number of bankruptcies.

Virolainen (2004) has showed on empirical data how the bankruptcy rate is affected by interest rates, GDP and aggregate indebtedness in various sectors of the economy. For the previous legislation, Jakubik (2007) introduced a model of bankruptcy prediction based on macroeconomic indicators. This model includes the effect of GDP, inflation, the share of private sector debt to GDP from 1998 to 2005.

\section{The Bankruptcy}

The bankruptcy is possible to divide into formal and material bankruptcy. About material bankruptcy is spoken if debtor fulfils the legal assumption of bankruptcy and has the obligation to fill bankruptcy petition. About formal bankruptcy is spoken when court declares bankruptcy. Act No. 182/2006 Coll., on Insolvency and its resolution, defines insolvency as the situation in that debtor has at least two creditors, has overdue claims and is unable to pay the most debts or has overdue claims at least for three months. Bankruptcy is one way how to solve the insolvency. According to previous Act No. 328/1991 Coll., on Bankruptcy and Composition was bankruptcy defined as the situation in which debtor is unable to pay its debts for longer time. There are little discrepancies between previous and current legislation, but according to my opinion, they are insignificant for this article. Main difference is application of Insolvency Act also on consumers therefore it will be counted only with

\footnotetext{
${ }^{1}$ The study focused on microeconomic data introduce, e.g.: Altman (1969) - bankruptcy prediction based on financial data from the company's balance sheet and profit and loss account, Beaver (1967) based bankruptcy prediction on the comparison cash flows with debt, Deakin (1972) deals with the Altman, Beaver and Deakin models and concludes that models prediction accuracy is about $90 \%$ in three year term.
} 
bankruptcies of entrepreneurs $^{2}$ in this article. Also the graph no. 1 shows the insignificance of discrepancies, because there was no substantial change in trend in year 2006, when the legislation had been changed. The main change was in the percentage of declared bankruptcies of entrepreneurs. The change in legislation causes the decrease of number of successful bankruptcy petitions. First, the low decline in 2007 could be explained by entrepreneurial subjects worrying about new legislation. Second, there is need of time to gain information about new insolvency law. Therefore, there is necessary to distinguish between the number of petitions filed and the number of declared bankruptcy. This article dealt with bankruptcy of entrepreneurial subjects. As the following graph shows, the number of petitions filed is significantly higher than the number of declared bankruptcies. First, not all proposals meet the legal requirements. Second, the bankruptcy petition is possible to take back. Third, there may happen that the bankruptcy is overcome. Fourth, court may deny bankruptcy petition. Fifth, some creditors also misuse the insolvency proceedings to create pressure on debtor instead of using civil proceedings. Therefore, only the number of declared bankruptcies includes businesses leaving the market and ceasing economic activity. That's why this indicator - number of declared bankruptcies - has better informative character for this analysis. Also the percentage of declared bankruptcies is different and it varies between 8 to 60 percent. The average percentage is 35 .

Figure 1: The Number of Bankruptcies of Entrepreneurs

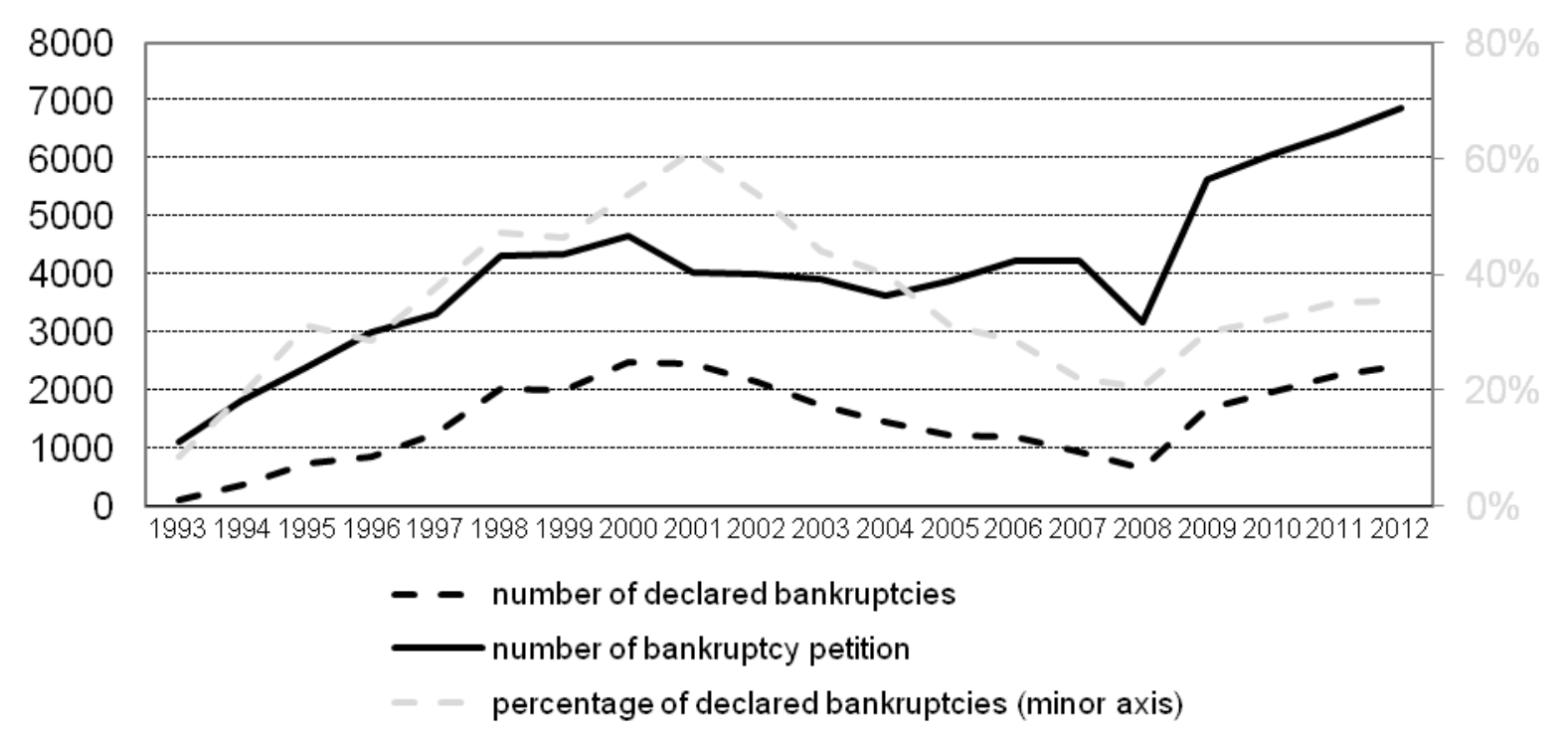

Source: Ministry of Justice Czech Republic

This article analyses number of declared bankruptcies of entrepreneurs and explain how the number of declared bankruptcies is affected by GDP (real annual growth of GDP in percentage), indebtedness of companies, inflation and interest rates. The article does not analyse the declared bankruptcies of consumers.

\footnotetext{
${ }^{2}$ Ministry of Justice changes methodology of insolvency statistics in 2008 because of new legislation. Therefore it will be made a little approximation of number of bankruptcy petitions of entrepreneurs in 2008-2012 in this article. The number of bankruptcy petitions of entrepreneurs is achieved as number of insolvency petitions minus insolvency petitions for debt discharge that might be only brought before court by consumers and minus insolvency petitions for reorganization that involves another way of solving insolvency than bankruptcy. Number of declared bankruptcies after 2008 involved sum of declared bankruptcies without bankruptcies transformed from debt discharge.
} 


\section{The Influence of macroeconomic determinants}

This part is focused on main subject matter of this article concerning how GDP, company's indebtedness, interest rate and inflation determine the number of declared bankruptcies of entrepreneurs in the Czech Republic. There are analyzed above mentioned variables covering the data from 1993 to 2012 and using the correlation analyses. The results are shown on graphs.

\subsection{The Influence of macroeconomic determinants}

It is possible to suppose that increasing GDP has negative effect on the number of declared bankruptcies. The higher GDP is, the less number of bankruptcies is declared. Higher GDP increases aggregate demand on the market and number of flourishing companies and vice versa. Higher GDP leads to the increase of aggregate demand due to acceleration effect. Vlieghe (2001 p. 27) said that there is relationship between increasing GDP and declining number of declared bankruptcies.

Is this relationship true in Czech Republic? Data covering period from 1993 to 2012 has correlation coefficient of -0.38 . When it is taken into account one year lag the correlation coefficient is -0.64 . The strongest correlation between GDP and number of declared bankruptcies is -0.68 if it is taken into account two years lag. The correlation coefficient is 0.40 for three years lag. This proves strong negative relationship between GDP and number of declared bankruptcies of entrepreneurs in two years lag. The increase of GDP causes the decline of declared bankruptcies. According to the graph no. 2, the development of GDP corresponds with the development of declared bankruptcies. Further, the graph no. 2 shows two year delay between the number of declared bankruptcies and GDP.

Figure 2: GDP and Number of declared bankruptcies of entrepreneurs

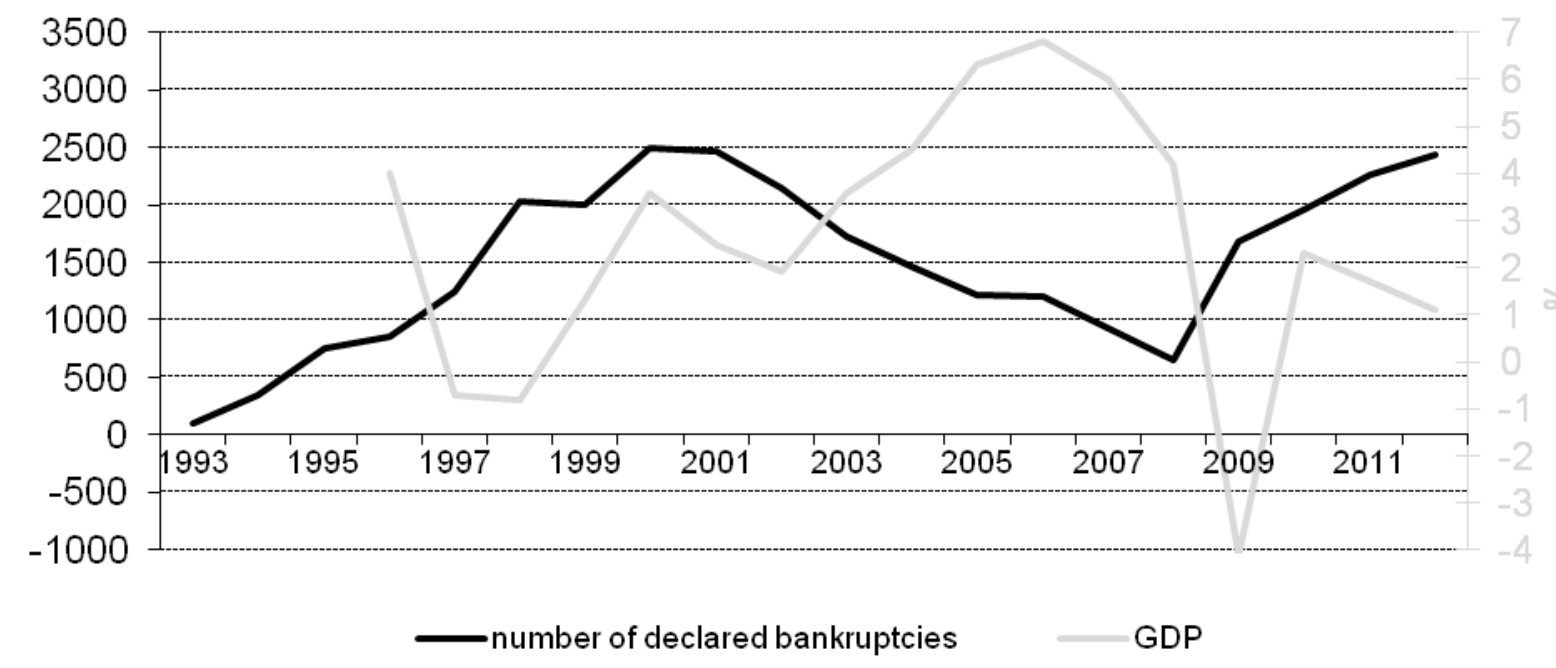

Source: Ministry of Justice Czech Republic, Czech Statistical Office

On the graph above, there is also possible to see negative consequence of economic recession between 1997 and 1999 on number of declared bankruptcies of entrepreneurs. The same could be seen in 2007, when GDP declined due to world recession. There raises a question, whether exists some direct mathematical relationship between GDP and the number of declared bankruptcies. The mathematical relationship has been analysed by Jakubík but he concluded there is not able to predict any exact coefficient (Jakubík, 2007 p. 14). 


\subsection{Company's loans}

There are two opinions how company indebtedness influences number of bankruptcies. Vlieghe (2001) has concluded in his study that the problem of indebtedness was caused by restriction of bank and problems with liquidity. Jakubík (2007 p. 14) has supposed influencing indebtedness by interest rate.

From my point of view problem of liquidity overweighs because there are worries about the future development and financial institutions do not want to lend money. Also there is no correlation between company's indebtedness and interest rates because correlation coefficient is only 0.15 . The problem of liquidity means that companies relying only on loan are unable to find finance for their project. Inability to find new resources and inability to find savings leads firms to submit bankruptcy petition because of payment incapacity.

According to Czech data from 1993 to 2012 there is correlation between company's indebtedness and number of bankruptcies. The correlation coefficient is 0.34 in the case of one year lag. In the case of two years lag the correlation coefficient is 0.65 . This correlation coefficient indicates positive relationship between company's loans and declared bankruptcy of entrepreneurs. Stronger relationship between company's indebtedness and number of bankruptcies is in two years lag. The strongest correlation is when there is taken into account three years lag. Then the correlation coefficient is 0.84 . On the graph no. 3 there is seen three years lag between the development on company's indebtedness and the number of declared bankruptcies. According to the graph no. 3 there higher company's indebtedness also leads to increased number of declared bankruptcies with three years delay.

Figure 3: Indebtedness of Companies and Number of declared bankruptcies

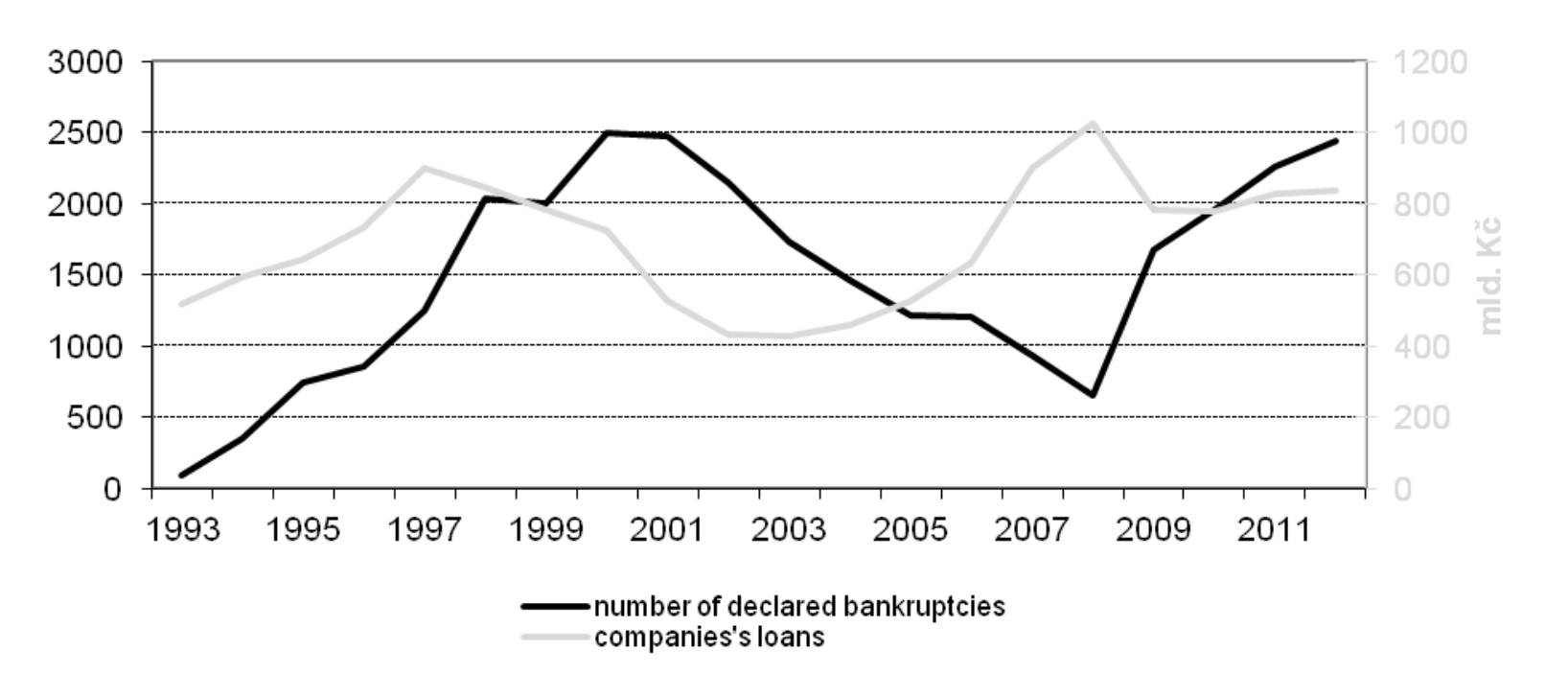

Source: Ministry of Justice Czech Republic, Czech National Bank

According to the graph no. 3 there could be seen similar volume of corporate lending in last period. Further according to the graph no. 3 and correlation there could be predicted turnover in increasing trend of number of declared bankruptcies of entrepreneurs in 2013.

\subsection{Interest rates}

Vlieghe (2001) has also examined the effect of interest rates on the number of bankruptcies. Vlieghe (2001 p. 10) has based his study on the theory that the selling of company's assets in order to repay debts leads to lower prices. According to Vlieghe (2001 p. 28), the real interest rate determines the number of declared bankruptcies in the long term and this conclusion is 
consistent with a deflationary theory. Contrary, Viroleinen (2004 p. 31) has failed to demonstrate the impact of real interest rates on the number of declared bankruptcies.

This article supposes the rise in interest rates causes increasing costs of debt financing. Further, increased debt financing costs would reduce earnings. There could be also assumed that increase of interest rates has different effect on companies according to the size of the company's debt. Moreover, there may be assumed greater impact of interest rates on heavily indebted firms. More indebted firms may not be able to cover the increased costs of funding. Therefore, the increasing of interest rate would cause higher declared bankruptcy rate.

This article uses annual rate of PRIBOR for analysis because there is similarity between development of annual rate of PRIBOR and real interest rate. The correlation coefficient between number of declared bankruptcies and average annual rate of PRIBOR is 0.42 indicating positive relationship. The correlation coefficient is 0.52 in the case of one year lag. Stronger correlation coefficient of value of 0.60 is in the case two years lag. The strongest correlation coefficient is 0.63 when is taken into account three year lag. The higher interest rate is, the more number of bankruptcies declares. On the graph no. 4 there is also seen three year delay between development of interest rates and the number of declared bankruptcies.

Figure 4: PRIBOR and Number of declared bankruptcies

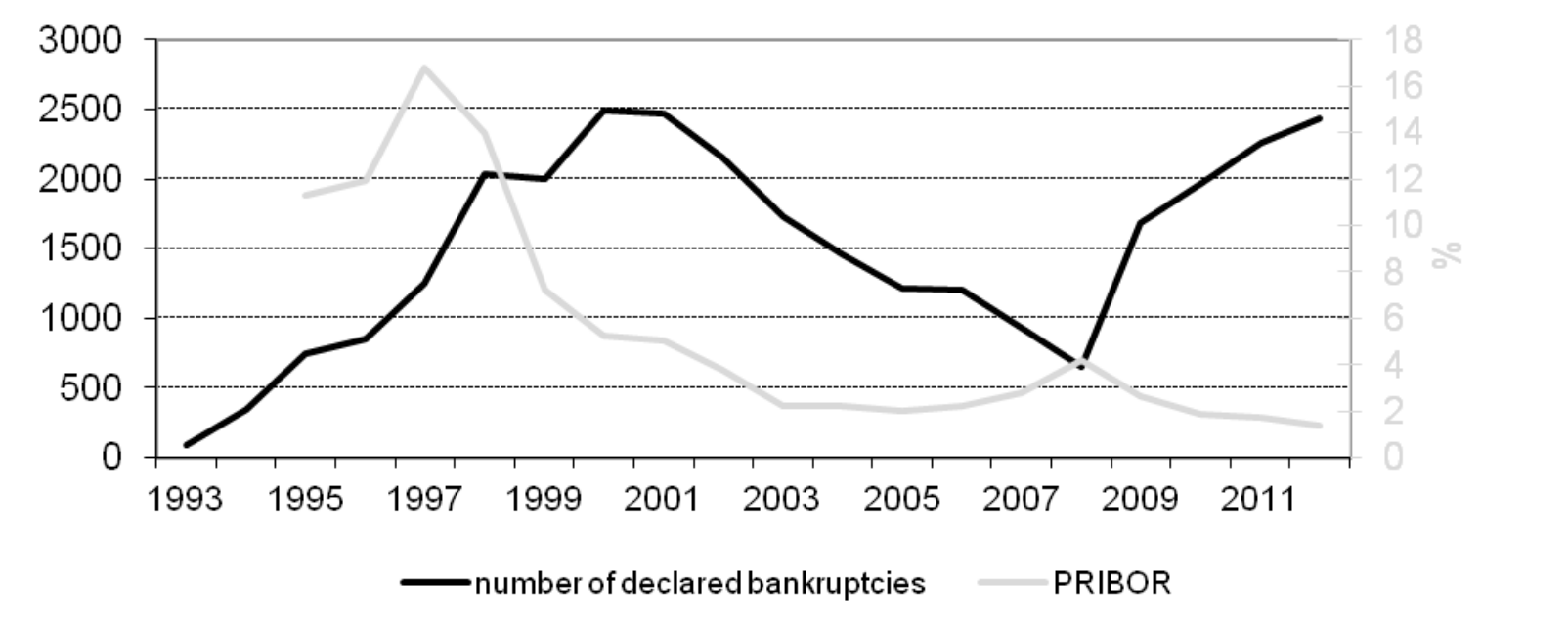

Source: Ministry of Justice Czech Republic, Czech National Bank

\subsection{Inflation}

Inflation may have short term effect on higher prices and thus profits in the long run outweigh its negative effects. Inflation may affect the status of the debtor because of the growing price level reducing the real value of debt and so the debtor's position could be improved. On the other hand, the lender is harmed. Above mentioned increase in price level previously expected, lenders transfer higher future inflation expectations into interest rates of loans. Therefore, the impact on the situation of companies is rather neutral. Liu (2004 p. 17) has said that inflation was likely to affect company cash flows and consequently impair the ability of firms to repay their obligations. Liu (2004) and Wadhwani (1986) confirmed the hypothesis that inflation increases the number of declared bankruptcies. Vlieghe (2001 p.9) has also supported the hypothesis about the negative effects of inflation, saying that the cost of inflation on debt management exceeds increased revenues. Supposing, this is also valid for Czech Republic. The correlation coefficient between inflation and declared bankruptcies is 0.61. The strongest correlation coefficient is 0.62 when it is taken into account one year lag. 
In the case of two years lag the correlation coefficient is 0.61 . There is positive relationship and therefore the higher inflation causes increasing of declared bankruptcies rate. The graph no. 5 shows the number of declared bankruptcies development and inflation in the years 1993 - 2012. There is seen that the number of declared bankruptcies is delay in the period of one year. Therefore it is possible to suppose overturn in increasing number of declared bankruptcies in 2012 and declining number of bankruptcies of entrepreneurs in 2013.

Figure 5: Inflation and Number of declared bankruptcies

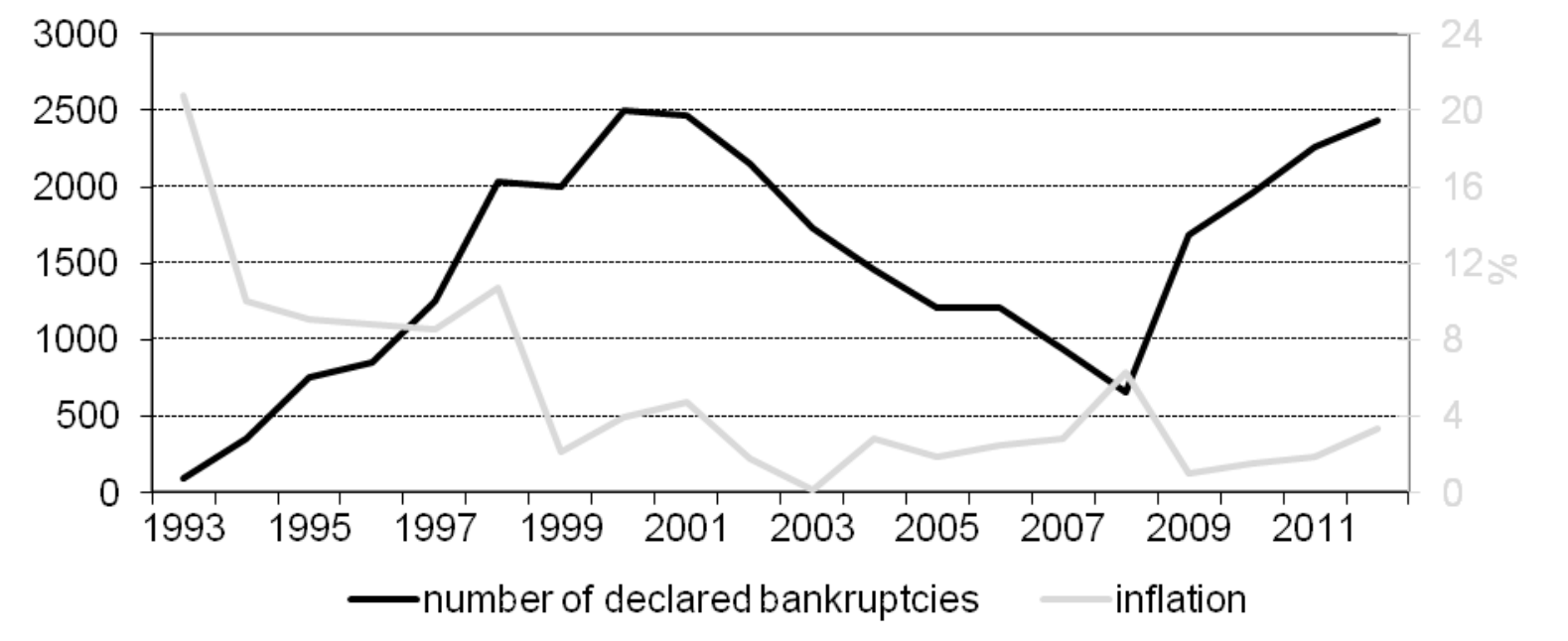

Source: Ministry of Justice, Czech statistical office

\section{Conclusion}

The insolvency law regulates company's exit from market in case the company fails. Higher and faster satisfaction of creditors and insolvency debtors leads to favourable market condition for borrowers and vice versa (Richter, 2008 p. 134). The role of insolvency law is to allow quick exit from the market for business in default. The number of exiting companies is influenced by number of declared bankruptcies. This article has analysed how the macroeconomic variables affected the number of declared bankruptcies in the Czech Republic. There is targeted on the relationship between macroeconomic variables and the declared bankruptcies of entrepreneurial subjects on data from 1993 to 2012. There is also predicted the trend of declared bankruptcies in following two years.

The analysis has found there is correlation between GDP and the number of declared bankruptcies, between company's indebtedness and the number of declared bankruptcies, between interest rates and the number of declared bankruptcies and between inflation and the number of declared bankruptcies.

The number of declared bankruptcies is negatively related to GDP and there is the lag of two years. The company's indebtedness is positively correlated with number of declared bankruptcies in horizon of three years. The growth of interest rate leads to increased number of declared bankruptcies and vice versa in three years lag. The number of declared bankruptcies is negatively affected by inflation. Higher inflation brings increasing number of declared bankruptcies and vice versa in one year lag.

According to the data from 1993 to 2012 there could be predicted future development of bankruptcies of entrepreneurs. There could be supposed overturn in rising number of declared bankruptcies in 2012 and declining number of declared bankruptcies in 2013, because there is 
above mentioned delay between macroeconomic variables and the number of declared bankruptcies. It is possible to predict only trend of declared bankruptcies but not exactly number of declared bankruptcies.

\section{Acknowledgement}

This article originated in research FMV VŠE paid by the institutionalized support for the development of research organizations.

\section{References}

[1] ALTMAN, I. E., 1969. Financial Ratios, Discriminant Analysis and the Prediction of Corporate Failure, The Journal of Finance, 23 (4), pp. 589 - 609. ISSN: 0022-1082.

[2] BEAVER, W., 1967. Financial Ratios as Predictors of Failure, Journal of Accounting Research, 5, Empirical research in Accounting: Selected Studies, pp 71-102. ISSN: 0021-8456.

[3] BERNHARDSEN, E., 2001. A model of bankruptcy prediction, Working Paper 2001/10, Norges Bank. ISSN 0801-2504.

[4] DEAKIN, E., 1972. A Discriminant Analysis of Predictors of Business Failure, Journal of Accounting Research, 10 (1), pp 167 - 179. ISSN: 0021-8456.

[5] CHARITOU, A., E. NEOPHYTOU and C. CHARALAMBOUS, 2004. Predicting Corporate Failure: Empirical Evidence for the UK, European Accounting Review, 13 (3), 465 - 497. ISSN 0963-8180.

[6] JAKUBÍK, P., 2007. Exekuce, bankroty a jejich makroekonomické determinant, IES Working Paper: 29/2007, IES FSV, Charles University [http://ies.fsv.cuni.cz]

[7] KOOPMAN, S. J., R. KRAUSSL, A. LUCAS and A. B. MONTEIRO, 2009. Credit cycles and macro fundamentals. Journal of Empirical Finance 16, 42-54. ISSN 09275398

[8] LIU, J., 2004. Macroeconomic determinants of corporate failures: evidence from the UK, Applied Economics, 36, pp. 939-945. ISSN 0003-684.

[9] OHLSON, J., 1980. Financial Ratios and the Probabilistic Prediction of Bankruptcy, The Journal of Accounting Research, 18 (1), pp. 109-131. ISSN: 0021-8456.

[10] RICHTER, T., 2008. Insolvenční právo. 1. vyd. Praha: ASPI, Wolters Kluwer. 471 p. ISBN 978-80-7357-329-4

[11] VIROLAINEN, K., 2004. Macro Stress Testing with a Macroeconomic Credit Risk Model for Finland, Bank of Finland, Discussion Paper, no. 18. [http://ssrn.com/abstract=622682]

[12] VLIEGHE, W. G., 2001. Indicators of fragility in the UK corporate sector, Monetary Assessment and Strategy Division, Working Paper, Bank of England. ISSN 1368-5562

[13] WADHWANI B. S., 1986. Inflation, Bankruptcy, Default Premia and Stock Market, The Economic Journal, 96 (381), pp. 120-138. ISSN 0013-013.

[14] WANG, T., 2010. Determinants of Corporate Default: Systematic Distress, Sectoral Distress and Credit Contagion, 23rd Australasian Finance and Banking Conference 2010 Paper [http://ssrn.com/abstract=1647576] 
[15] Ministry of Justice (1994) PREH1994 Statistická ročenka soudních agend I za rok 1994 available at [http://cslav.justice.cz/InfoData/statisticke-rocenky.html] cited on 29.9.2010

[16] Ministry of Justice (1995) PREH1995 Statistická ročenka soudních agend I za rok 1995 available at [http://cslav.justice.cz/InfoData/statisticke-rocenky.html] cited on 29.9.2010

[17] Ministry of Justice (1996) PREH1996 Statistická ročenka soudních agend I za rok 1996 available at [http://cslav.justice.cz/InfoData/statisticke-rocenky.html] cited on 29.9.2010

[18] Ministry of Justice (1997) PREH1997 Statistická ročenka soudních agend I za rok 1997 available at [http://cslav.justice.cz/InfoData/statisticke-rocenky.html] cited on 29.9.2010

[19] Ministry of Justice (1998) PREH1998 Statistická ročenka soudní agendy I za rok 1998 available at [http://cslav.justice.cz/InfoData/statisticke-rocenky.html] cited on 29.9.2010

[20] Ministry of Justice (1999) PREH1999 Statistická ročenka soudní agendy I za rok 1999 available at [http://cslav.justice.cz/InfoData/statisticke-rocenky.html] cited on 29.9.2010

[21] Ministry of Justice (2000) PREH2000 Statistická ročenka soudní agendy I za rok 2000 available at [http://cslav.justice.cz/InfoData/statisticke-rocenky.html] cited on 29.9.2010

[22] Ministry of Justice (2001) PREH2001 Statistická ročenka soudní agendy I za rok 2001 available at [http://cslav.justice.cz/InfoData/statisticke-rocenky.html] cited on 29.9.2010

[23] Ministry of Justice (2002) PREH2002 Statistická ročenka soudní agendy I za rok 2002 available at [http://cslav.justice.cz/InfoData/statisticke-rocenky.html] cited on 29.9.2010

[24] Ministry of Justice (2003) PREH2003 Statistická ročenka soudní agendy I za rok 2003 available at [http://cslav.justice.cz/InfoData/statisticke-rocenky.html] cited on 29.9.2010

[25] Ministry of Justice (2004) PREH2004 Statistická ročenka soudní agendy I za rok 2004 available at [http://cslav.justice.cz/InfoData/statisticke-rocenky.html] cited on 29.9.2010

[26] Ministry of Justice (2005) PREH2005 Statistická ročenka soudní agendy I za rok 2005 available at [http://cslav.justice.cz/InfoData/statisticke-rocenky.html] cited on 29.9.2010

[27] Ministry of Justice (2006) Rocenka2006 Statistická ročenka soudní agendy I za rok 2006 available at [http://cslav.justice.cz/InfoData/statisticke-rocenky.html] cited on 29.9.2010

[28] Ministry of Justice (2007)Rocenka2007 Statistická ročenka soudní agendy I za rok 2007 available at [http://cslav.justice.cz/InfoData/statisticke-rocenky.html] cited on 29.9.2010

[29] Ministry of Justice (2008a) Rocenka2008 Statistická ročenka soudní agendy I za rok 2008 available at [http://cslav.justice.cz/InfoData/statisticke-rocenky.html] cited on 29.9.2010

[30] Ministry of Justice (2008b) Statistické údaje za rok 2008 available at [http://insolvencnizakon.justice.cz/expertni-skupina-s22/statistiky.html] cited on 20.3.2013

[31] Ministry of Justice (2009) Statistické údaje za rok 2009 available at [http://insolvencnizakon.justice.cz/expertni-skupina-s22/statistiky.html] cited on 20.3.2013

[32] Ministry of Justice (2010) Statistické údaje za rok 2010 available at [http://insolvencnizakon.justice.cz/expertni-skupina-s22/statistiky.html] cited on 20.3.2013

[33] Ministry of Justice (2011) Statistické údaje za rok 2011 available at [http://insolvencnizakon.justice.cz/expertni-skupina-s22/statistiky.html] cited on 20.3.2013

[34] Ministry of Justice (2012) Statistické údaje za rok 2012 available at [http://insolvencnizakon.justice.cz/expertni-skupina-s22/statistiky.html] cited on 20.3.2013 
[35] Czech National Bank Databáze časových řad ARAD available at [http://www.cnb.cz/cnb/STAT.ARADY_PKG.STROM_DRILL?p_strid=0\&p_lang=CS] cited on 21.3.2012

[36] Czech National Bank Roční sazby PRIBOR available at [http://www.cnb.cz/cs/financni_trhy/penezni_trh/pribor/rok_form.jsp] cited on 21.3.2012

[37] Czech Statistical Office Statistiky available at [http://www.czso.cz/csu/redakce.nsf/i/statistiky] cited on 21.3.2012 